\title{
Destination New Zealand: A history of the Afrikaans Christian Church of New Zealand
}

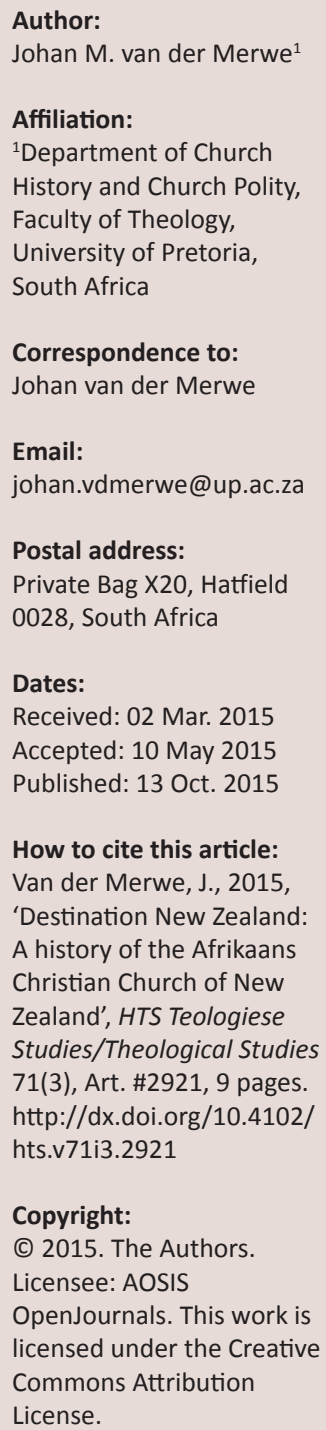

The advent of democratic change in South Africa in the 1990s led to an exodus of many White Afrikaans-speaking Christians from South Africa. They settled all over the world. One of the countries of choice was New Zealand. A group of these emigrants came together in Auckland, New Zealand, in 1998 and founded an Afrikaans church. The Church grew from one congregation to a denomination that currently has nine congregations. This article describes the history of the Afrikaanse Christen Kerk van Nieu-Seeland [Afrikaans Christian Church of New Zealand]. It focuses on the founding, growth, Church Order, ministry and challenges of the Church. The sources for this article are primary documents collected by the author in New Zealand.

\section{Introduction}

With the advent of democratic change in South Africa at the end of the previous century, numerous White Afrikaans-speaking South Africans decided to leave the country. Many of them immigrated to New Zealand. Statistics confirm this. According to statistics of the New Zealand Department of Home Affairs, there were 3840 South African born citizens in New Zealand in 1976, 26061 in 2001, 41676 in 2006 and 54279 in 2013. The people that had left South Africa for New Zealand stated the high crime rate, crumbling infrastructure, corruption, affirmative action, and a lack of faith in African leadership as reasons for their decision (De Vries 2012:339-362). Rademeyer (2010:4) confirmed these numbers in 2010 by saying that there were nearly 380000 South Africans living abroad.

This article is the result of a visit by the author to New Zealand to do research on the founding of the Afrikaans Christian Church of New Zealand (ACC) in order to document the history of the Church. Because of the lack of secondary sources on the history of this specific Church, the author had to make use of agendas, minutes and other church documents. Extensive interviews were held with important role players who were involved in the founding of the Church. All of these are reflected in the bibliography of this article. In order to describe the founding of the Church, the article will focus on the migration of Afrikaans-speaking people to New Zealand and the establishment of the first congregation in Auckland, New Zealand. It will then describe the growth of the ACC, the organisation of Church Order and the ministry of the Church before concluding with the challenges as identified by the ministers of the ACC.

\section{Destination New Zealand}

As already stated in the introduction, the advent of democratic change in South Africa in 1994 led to the emigration of many South Africans to other countries. This statement is confirmed by Marchetti-Mercer and Roos (2006) when they state:

During the apartheid years a number of migratory fluxes took place, often linked to specific political events. However, a definite trend can be observed in post-apartheid South Africa, where a new surge of the population has chosen to leave the country. The people who emigrate tend to be highly skilled, hence this kind of migration is often referred to as a 'brain drain' depriving South Africa of much-needed professional and technical expertise (p. 55)

Different reasons are provided for these emigrations. Marchetti-Mercer and Roos mention that Afrikaans-speaking inhabitants experienced a sense of alienation and loss in the 'new' South Africa, which may have influenced their decision to leave. Other reasons leading to the decision to emigrate included socio-political factors, a need for change and/or professional improvement, and wanting to provide better opportunities for one's children. Exact statistics on the number of people that have left are not always available because many of the would-be emigrants do not indicate their intention to emigrate on departure from South Africa. Statistics South Africa published a report in July 2010 which indicated that more than half a million South Africans had left the country after 1994 (Marchetti-Mercer \& Roos 2013:5). The main reasons given for 
emigration were violence, crime and corruption (82\%). Other motivating factors were an unstable economy, (31\%), government $(31 \%)$, discrimination $(7 \%)$ and infrastructure (3\%). This is confirmed by Van Rooyen (2000) when he says the following:

Crime has become the country's Achilles heel - no matter what progress has been made in reconstruction, reconciliation, nation building and even economic miracles, these will remain empty words if the citizens of the country are subject to a level of violent crime akin to a 'civil war' that never happened. (p. 97)

Interviews conducted by the author in New Zealand confirm this. All the emigrants interviewed mentioned crime and corruption as the main reasons why they decided to leave the country (Johan van der Merwe, pers. comm., 30 August 16 September 2012).

\section{The founding of the first congregation}

When Jan van Riebeeck arrived in the Cape in 1652 to establish a refreshment post for Dutch ships en route to India, he also brought the reformed Church with him (Van der Watt 1975:4). The same pattern continued with emigrants leaving South Africa for New Zealand. Many of the emigrants who left South Africa and went to New Zealand were devoted Christians, and they took their faith with them. Although some became members of the different Reformed Churches in New Zealand, the need for an Afrikaans church became more apparent as more and more emigrants arrived (Afrikaanse Christen Kerk van Nieu-Seeland 1998g). The emigrants spontaneously formed Bible-study groups and began with an Afrikaans church service in the buildings of the Holy Trinity Methodist Church in North Shore, Auckland. Rev Dawie Kriel, formerly from the Nederduitsch Hervormde Kerk in Afrika in South Africa, and at that time minister of the Presbyterian Church in Te Kauwhata, was approached for an Afrikaans church service once a month. Due to the demand, once a month soon became every Sunday. Gradually, the people who attended started seeing themselves as a congregation (Afrikaanse Christen Kerk van Nieu-Seeland 1998g). This statement is confirmed by the minutes of the working group who formally founded the first congregation. It states: 'The purpose of this committee is to study the structures of established churches in order to make certain proposals to the congregation' (Afrikaanse Christen Kerk van Nieu-Seeland 1998h:2, own translation). Although they saw themselves as a congregation, it was in one of the Bible-study groups that the decision was taken under the leadership of François Schoeman to formally establish an Afrikaans church in North Shore, Auckland. A 'working group' was formed, which convened for the first time on 02 September 1998 (Afrikaanse Christen Kerk van Nieu-Seeland, 1998h:1).

The members of the group were Francios Schoeman, Magda Schoeman, Pieter Grobler, Arina Grobler, Juanita Steyn, Koos Kocks, Thinus Spies, Niko Kiers, Christiaan Lubbe, Bert Fourie, Franz Wendzich, Johan Pretorius, Nicky Verryene,
Harry Nortjie and Andries van der Westhuizen (Afrikaanse Christen Kerk van Nieu-Seeland 1998h:2). The purpose of the meeting was clearly stated in the minutes:

To discuss the activities of the community. The working group organised themselves in several sub-committees and this was already a reflection of how they thought an official church could look like. The different committees were Church structure, Sunday school, Finance, Weekly sermons, Auckland South, Bible study groups, Youth and Women. The working group also decided to ask Rev Dawie Kriel and Rev Stanley Theron to conduct the Sunday worship services. (Afrikaanse Christen Kerk van Nieu-Seeland 1998h:2-3)

This first meeting was followed by meetings on 14 September and 21 September 1998. During these meetings, further planning for the founding of the new Church was discussed (Afrikaanse Christen Kerk van Nieu-Seeland 1998i, 1998j). During the meeting of 21 September, the first official proposal for the founding of a new Afrikaans church was tabled. According to the introduction to the proposal, $68 \%$ of known Afrikaans emigrant families indicated in a questionnaire that they preferred an Afrikaans church which was not linked to a present denomination. Furthermore, $22 \%$ of respondents preferred an Afrikaans congregation linked to an English New Zealand church, and 10\% indicated that they preferred an Afrikaans congregation linked to an Afrikaans church in South Africa (Afrikaanse Christen Kerk van Nieu-Seeland 1998k:1). The proposal further defined the mission of the Church as an independent church in New Zealand with the sole purpose of accommodating Afrikaansspeaking believers and their children in New Zealand. The final document for the founding of the new Church was ready by 07 October 1998. The preamble of this document read as follows: VESTIGING VAN 'N ONAFHANKLIKE AFRIKAANSE GEREFORMEERDE KERK op DV 01 November 1998 om 12:00 nm in die Trinity Methodist Church, Beach Rd, Browns Bay Auckland. [FOUNDING OF AN INDEPENDENT AFRIKAANS REFORMED CHURCH, deo volente on 01 November 1998 at 12:00 pm in the Trinity Methodist Church, Beach Rd, Browns Bay, Auckland, own translation]. The document made it clear that the new Church would be independent from all other churches, but that Englishspeaking members would be welcome and that ecumenical relationships with other churches would be a priority (Afrikaanse Christen Kerk van Nieu-Seeland 1998d). The confessional basis of the Church was described as the Bible, the 12 Articles, the creeds of Nicea and Athanasius, as well as the three Reformed confessions of faith, namely the Confessio Belgica, the Heidelberg Catechism and the Canons of Dordt (Afrikaanse Christen Kerk van Nieu-Seeland 1998d). It was decided that, during the founding church service on 01 November 1998, a Church Council would be elected and confirmed and that the members of the new Church would have the opportunity to vote on the name of the Church (Afrikaanse Christen Kerk van Nieu-Seeland 1998d).

On 01 November 1998, the Afrikaanse Christen Kerk van Nieu-Seeland [Afrikaans Christian Church of New Zealand] was officially founded in the Trinity Methodist Church, Beach 
Road, Browns Bay, Auckland. Several proposals for the name of the Church were received. They were: The Protestantse Afrikaanse Kerk van New Zealand, Onafhanklike Aotearoa Gereformeerde Kerk, Afrikaanse Kerk, Die Onafhanklike Afrikaanse Kerk, Afrikaanse Christen Kerk van New Zealand and Nieu-Seeland Protestantse Kerk. The congregation decided on the Afrikaanse Christen Kerk van Nieu-Seeland with a majority vote (Afrikaanse Christen Kerk van NieuSeeland 1998c). It is clear that a name with any connotation to the Afrikaans sister churches in South Africa was deliberately avoided so that all Afrikaans-speaking Christians from the reformed faith would feel at home in the new Church. The first elders who were chosen were the following: Eric Filmater, JC Joubert, Nico Kiers, Harry Nortje, Herman Roodt, Francois Schoeman, Chris Venter and Franz Wendzich (Afrikaanse Christen Kerk van Nieu-Seeland 1998f). The first deacons were the following: D. Grey, F. Kruger, C. Lubbe, L. Nortje, L. Oberholzer, M. Schoeman, B. van der Merwe and K van Heerden (Afrikaanse Christen Kerk van Nieu-Seeland 1998e). The first Church-Council meeting was held on 05 November 1998 and was chaired by the Rev Dawie Kriel. At first, Church-Council meetings were held once a week to monitor the progress of the new Church. Besides practical ministry issues such as worship and catechesis, the Church Council gave attention to setting up a Church ordinance, policy-making and the registration of the Afrikaanse Christen Kerk van Nieu-Seeland as an official church in New Zealand (Afrikaanse Christen Kerk van Nieu-Seeland 1998g).

Due to commitments in his own congregation, the Rev Kriel could not continue with the Afrikaans services. However, he contacted the Rev Gawie Cloete who lived in Hamilton and worked as a salesman. Cloete agreed to conduct a worship service in Auckland once a month. In June 1999, the Church Council asked the Rev Cloete to become the first full-time minister of the Church in Auckland. He accepted and became the first full-time minister of the Afrikaanse Christen Kerk van Nieu-Seeland on 12 July 1999 (Afrikaanse Christen Kerk van Nieu-Seeland 1999d). The Afrikaanse Christen Kerk van Nieu-Seeland was now a reality. This is confirmed by the official recognition that the Church received from the Presbyterian Church of Aotearoa in New Zealand. In a letter written by Kerry Enright, Executive Secretary of the Presbyterian Church, dated 28 July 1999, he wrote the following: 'On behalf of the Presbyterian Church of Aotearoa New Zealand I wish to welcome your Church into the family of Reformed Churches in New Zealand'. He, Kerry Enright, (Presbyterian Church of Aotearoa 1999) further wrote: 'We would like to establish close relationships with your church'.

\section{Expansion and growth}

It did not take long before the new Church grew from one congregation in North Shore to a congregation with more than one ministry point. Approximately at the same time as the establishment of the Afrikaanse Christen Kerk van Nieu-Seeland, Dr Stanley Theron, an Afrikaans-speaking minister from South Africa, began with worship services for a group of Afrikaans-speaking Christians in the Howick area in the South Eastern suburbs of Auckland. Theron, a minister of the Dutch Reformed Church, was sent from South Africa as part of an outreach to Afrikaans-speaking Christians in New Zealand. As a result of his work, a group of Afrikaans-speaking Christians came together in a group which called themselves the Independent Reformed Church of Howick (Onafhanklike Gereformeerde Kerk van Howick 1999). Soon after the founding of the Afrikaanse Christen Kerk van Nieu-Seeland in North Shore, discussions about cooperation between the two churches began. Although Theron was not in favour of unification, cooperation between the two churches was seen as of the utmost importance. His point of view about unification was, however, not shared by many of the members of his group. During a first meeting of representatives of the two churches on 28 June 1999, a possible future unification was mentioned (Notule van 'n Gesamentlike Vergadering: North Shore en Howick, 28 June 1999). In a letter dated 26 July 1999, mention had already been made of the possibility of one denomination with two congregations, namely, North Shore and Howick. Although it took almost a year of meetings and discussions, the decision to establish one congregation with two ministry points was taken unanimously by a combined meeting of the representatives of the two churches on 10 July 2000 (Notule van 'n Gesamentlike Vergadering: North Shore en Howick, 10 Julie 2000:1). At a combined meeting of the Church Councils of the ACC and the Independent Reformed church of Howick on 14 August 2000 in Browns Bay, the decision to form one congregation was formally taken (Notule van 'n Gesamentlike Vergadering: North Shore en Howick, 14 Augustus 2000:1). Although there was some resistance against the unification, the decision was taken unanimously. A committee was named to facilitate the unification process. The Rev Gawie Cloete was named chair with Hannes Joubert, Francios Schoeman, Fanie Nel, Chris Venter, Rudolph Nortje, Piet Meiring, Barry Meyer, Dr Stanley Theron, Cobus van der Walt and Herman Steyn as additional members (Notule van 'n Gesamentlike Vergadering: North Shore en Howick, 14 Augustus 2000:3). The committee had to facilitate the structure of the church in Howick. The unification was officially approved by the congregation of the ACC on 27 August 2000 when the following proposal was accepted: 'The two church councils propose that one church with one congregation is established with the ideal that Howick could become a second congregation of the church.' The first church service of the ACC was held on 10 September 2000 (Afrikaanse Christen Kerk van Nieu-Seeland 2000). The new Church grew steadily. The minutes of the Church Council of 09 August 2001 mentioned that the church building in North Shore was becoming too small for the Sunday services, and a decision was taken to look for a larger venue as a matter of urgency (Afrikaanse Christen Kerk van Nieu-Seeland 2001a:2). By November 2001, membership had grown to such an extent that the Church Council decided to appoint a second minister. The executive was tasked to facilitate the process (Afrikaanse Christen Kerk van Nieu-Seeland 2001b:2). By 15 May 2001, 132 applications had been received. After a lengthy process, Dr Stephan Joubert was called as second minister 
of the Afrikaanse Christen Kerk van Nieu-Seeland at a special meeting of the Church Council. His appointment was approved by a meeting of the congregation on 09 June 2002 (Afrikaanse Christen Kerk van Nieu-Seeland 2002). He was confirmed as minister of the Church on 01 September 2002. Although Joubert returned to South Africa in 2003 and was succeeded by the Rev Johan Lotter who took responsibility for the ministry in Howick, the Church kept growing. Rev Johan Hendricks of Hamilton commented on Jouberts's ministry in Auckland by saying that 'Dr Joubert came and opened up the minds of the church' (Johan Hendricks, pers. comm., 10 September 2012). This is confirmed by a report on further growth in the congregation in May 2003. Membership grew from 573 in 2002 to 755 in 2003, and by 2005 the congregation had more than a thousand members (Afrikaanse Christen Kerk van Nieu-Seeland 2003a:2). In 2006, it was decided to form two separate congregations within one denomination (Thys Oosthuizen, pers. comm., ${ }^{1} 30$ August 2012). This decision was necessitated by further growth of the Church in areas outside of Auckland.

In the minutes of the combined meeting of the Church Council of 28 August 2003, mention is made of a ministry point in Hamilton. In a report to the executive of the Church Council, it was reported that extensive research was done on the feasibility of ministry in the Hamilton area, and it was proposed that church services should commence as soon as possible. The first official church service of the ACC was held in Hamilton by the Rev Johan Hendricks on 17 August 2003 and was attended by 80 people (Afrikaanse Christen Kerk van Nieu-Seeland 2003b:2). The ministry in Hamilton expanded in such a way that members of the Church decided to request that Hamilton could become an official second congregation of the Afrikaanse Christen Kerk van NieuSeeland (Afrikaanse Christen Kerk van Nieu-Seeland 2004a). On 16 May 2004, the request was granted, and Hamilton became the second official congregation of the Afrikaanse Christen Kerk van Nieu-Seeland (Afrikaanse Christen Kerk van Nieu-Seeland 2004b). This opened the way for dividing the Auckland congregation into two separate congregations. At a combined meeting of the congregation, the target date was set for 01 April 2006. On 02 April 2006, Howick became the third congregation of the ACC (Thys Oosthuizen, pers. comm., 30 August 2012). The ACC was now a denomination consisting of three separate congregations. The first general assembly of the Church took place on 14 May 2005 in Hamilton (Afrikaanse Christen Kerk van Nieu-Seeland 2005a:2). The Rev Johan Hendricks was elected as the first chairperson and the Rev Johan Lotter as secretary. During this meeting, five goals were accepted for the ACC. They were: worship, family-centred ministry, caring, discipleship and missions. At the second General Assembly which took place on 26 May 2006 in Howick, Auckland, the Rev Johan Hendricks said: 'The ACKNZ grew in two years from one congregation to a Church with four congregations and four permanent ministers. It is exciting times' (Afrikaanse Christen Kerk van Nieu-Seeland 2006b:2).

1.Thys Oosthuizen was one of the founding members of the church.
As more and more emigrants arrived in New Zealand, more congregations were established: Rotorua and Wellington followed in 2006. A third congregation was established in Auckland in 2007. The founding of this congregation was the result of a split in the congregation in North Shore. After the Rev Gawie Cloete left the congregation in August 2005 (Afrikaanse Christen Kerk van Nieu-Seeland 2005b), the Rev Danie Marais was called to the congregation in North Shore. His arrival led to changes in ministry and in the structure of the congregation. Spiritual change followed with the introduction of a band for praise and worship. These and other changes led to tension in the congregation. One example of the growing tension was the participation of children in Holy Communion. After a survey in the congregation where 35 participants voted in favour and 43 against, the Church Council decided that children would not be allowed to partake in Holy Communion. The Rev Marais indicated that he did not support the decision (Afrikaanse Christen Kerk van Nieu-Seeland 2006a). At the meeting of the congregation on 26 November, even greater division arose on the issue. It was decided that a commission would be appointed to study the issue further (Afrikaanse Christen Kerk van Nieu-Seeland 2006c). The discontent amongst certain groups of the congregation is further illustrated by a letter to the Executive of the General Assembly of the Church. In meetings that followed, separate church services, one formal and one informal, or a separate congregation were proposed by Thys Oosthuizen, spokesperson of the group (Afrikaanse Christen Kerk van Nieu-Seeland 2007e). After a facilitation process of several months, it became clear that a separate congregation was inevitable (Afrikaanse Christen Kerk van Nieu-Seeland, 2007f). Auckland congregation was formally founded on 01 March 2007, and the Rev T Riekert was called as first minister. By 2012, the Church consisted of eleven congregations. Nine congregations were on the North Island in Auckland, Hamilton, Hawkes Bay, Howick, North Hore, Rotorua, Tauranga, Wellington and Whangarei. Two congregations were on the South Island in Christchurch and Greymouth (Afrikaanse Christen Kerk van Nieu-Seeland 2012:1). Since 2012, one congregation, Greymouth, closed its doors due to demographic changes after the local mine was closed. The latest statistics for the ACC are as follows: (members in brackets) Auckland (133), Christchurch (90), Hawkes Bay (84), Howick (392), North Shore (511), Roturua (55), Tauranga (58), Hamilton (439), Wellington (43) and Whangarei (43) (Afrikaanse Christen Kerk van Nieu-Seeland 2015).

The tension in North Shore and the eventual split confirms the complexity of ministry in the different congregations. Members came from different denominations in South Africa and therefore had different expectations of the ministry. They also came from different spiritual backgrounds which made ministry even more challenging. It also makes the Afrikaanse Christen Kerk van Nieu-Seeland a true ecumenical Church, which poses important challenges to the Church Order of the Church (Jaco Reynecke, pers. comm., 30 August 2012). This complexity as well as the growth of the Church led the general 
meeting to decide to form a working group to rewrite the Church Order (Afrikaanse Christen Kerk van Nieu-Seeland 2006b:6). The importance of this issue is underlined by the fact that a special second General Assembly was scheduled for 02 September 2006 in North Shore, Auckland (Afrikaanse Christen Kerk van Nieu-Seeland 2006b:6)

\section{A Church Order for the Afrikaanse Christen Kerk van Nieu-Seeland}

From the formation of the first congregation, the importance of a Church Order was realised, not only to manage the congregation but in order to open a bank account and register the Church in New Zealand. The first meeting of the Church Order Committee took place on 18 February 1999 (Afrikaanse Christen Kerk van Nieu-Seeland 1999b). At the second meeting of the Committee, it was decided to study the Church Orders of the four main churches in South Africa and to use the outcome of this study as a point of departure (Afrikaanse Christen Kerk van Nieu-Seeland 1999c). The first official Church Order of the Church was approved in 1999, and the sources of this original Church Order were evident. It was a composition of the different Church Orders of the Dutch Reformed Church, the Nederduitsch Hervormde Kerk van Afrika, the Gereformeerde Kerk and the Afrikaanse Protestantse Kerk. However, it did not reflect the ecumenical character of the Church, a fact that called for the urgent revision of the Church Order (Johan Hendricks, pers. comm., 10 September 2012)

The growth of the Church also brought new organisational challenges. Since 2004, the Church no longer had one congregation only, but four congregations. This led to the first general assembly in 2005, but it also posed important challenges to the structure of and the order in the Church. The previously mentioned ecumenical character of the Church also posed a huge challenge. Although the church wanted to be ecumenical in nature, it was not prepared to let go of its reformed roots (Johan Hendricks, pers. comm., 10 September 2012).

The first revision of the Church Order of the ACC was approved on 09 September 2006. It was revised again on 18 September 2009, and these revisions were implemented in March 2010. The revised Church Order was compiled after a long consultation process which was facilitated by the Rev Johan Hendricks who was chairman of the general assembly of the church (Johan Hendricks, pers. comm., 10 September 2012). The revised Church Order consists of 13 chapters and one regiment. The following table gives a comparative overview of the initial and latest Church Orders (Table 1).

Although there are many similarities, the difference between the two Church Orders shows the evolution and growth which have taken place in the church since 1999. The bylaw on locally ordained ministers (3.2) as well as the chapters on the General Assembly, majorities in decision-making, and
TABLE 1: Church Order of the Afrikaans Christian Church.

\begin{tabular}{|c|c|}
\hline The Church Order of 1999 & The Church Order of 2010 \\
\hline $\begin{array}{l}\text { Mission: To create a spiritual home } \\
\text { for Afrikaans-speaking Christians }\end{array}$ & $\begin{array}{l}\text { Mission: To create a spiritual home for } \\
\text { mainly Afrikaans-speaking Christians }\end{array}$ \\
\hline $\begin{array}{l}\text { 1. The Church } \\
\text { 1.1 The confession of faith of the } \\
\text { church } \\
\text { 1.2 Membership } \\
\text { 1.3 Church governance } \\
\text { 1.4 Services } \\
\text { 1.5 Relationship with other } \\
\text { churches }\end{array}$ & $\begin{array}{l}\text { 1. The Church } \\
\text { 1.1 The confession of faith of the } \\
\text { church } \\
\text { 1.2 Membership } \\
\text { 1.3 Church Governance } \\
\text { 1.4 Relationship with other churches }\end{array}$ \\
\hline $\begin{array}{l}\text { 2. The Congregation } \\
\text { 2.1 Definition of a congregation } \\
2.2 \text { Formation of new } \\
\text { congregations } \\
2.3 \text { Incorporation of existing } \\
\text { congregations }\end{array}$ & $\begin{array}{l}\text { 2. The Congregation } \\
\text { 2.1 Definition of a congregation } \\
2.2 \text { Formation of a new congregations } \\
2.3 \text { Incorporation of existing } \\
\text { congregations/churches }\end{array}$ \\
\hline $\begin{array}{l}\text { 3. Church meetings } \\
\text { 3.1 Session } \\
\text { 3.2 Congregation meeting } \\
\text { 3.3 Elders meeting } \\
\text { 3.4 Deacons }\end{array}$ & $\begin{array}{l}\text { 3. The Offices } \\
\text { 3.1 Minister } \\
\text { 3.2 Ordaining of ministers } \\
\text { 3.3 Elders } \\
\text { 3.4 Deacons } \\
\text { 3.5 Election and term of office: elders } \\
\text { and deacons } \\
\text { 3.6 Paid personnel }\end{array}$ \\
\hline $\begin{array}{l}\text { 4. Offices } \\
\text { 4.1 Minister } \\
\text { 4.2 Elders } \\
\text { 4.3 Deacons }\end{array}$ & $\begin{array}{l}\text { 4. Meetings of the congregation } \\
4.1 \text { Congregation meeting } \\
4.2 \text { Session } \\
\text { 4.3 Managing board } \\
\text { 4.4 Financial Committee }\end{array}$ \\
\hline $\begin{array}{l}\text { 5. Proclamation of the Word and } \\
\text { liturgy } \\
\text { 5.1 Church services } \\
5.2 \text { Participation in worship } \\
5.3 \text { Liturgy } \\
\text { 5.4 Christian festivals } \\
\text { 5.5 Special worship services }\end{array}$ & $\begin{array}{l}\text { 5. General assembly } \\
5.1 \text { Composition } \\
5.2 \text { Meetings } \\
5.3 \text { Functions }\end{array}$ \\
\hline $\begin{array}{l}\text { 6. Sacraments and teaching } \\
\text { 6.1 Definition of the sacraments } \\
\text { 6.2 Service of the sacraments } \\
\text { 6.3 Participation } \\
\text { 6.4 Teaching }\end{array}$ & 6. Majorities in decision making \\
\hline 7. Evangelization and mission & $\begin{array}{l}\text { 7. Preaching of the Word } \\
\text { 7.1 Participation and conducting of the } \\
\text { worship service } \\
\text { 7.2 Liturgy } \\
\text { 7.3 Formularies } \\
\text { 7.4 Singing and music } \\
\text { 7.5 Christian festivals } \\
\text { 7.6 Special worship services }\end{array}$ \\
\hline $\begin{array}{l}\text { 8. Relationships with other } \\
\text { institutions } \\
8.1 \text { Other churches } \\
8.2 \text { Public institutions } \\
8.3 \text { Media }\end{array}$ & $\begin{array}{l}\text { 8. Sacraments } \\
\text { 8.1 Administering of the sacraments } \\
8.2 \text { Baptism } \\
8.3 \text { Holy communion }\end{array}$ \\
\hline 9. Charity & $\begin{array}{l}\text { 9. Teaching } \\
\text { 9.1 Faith teaching } \\
\text { 9.2 Teaching of members } \\
\text { 9.3 Equipping of offices } \\
\text { 9.4 Spreading of the gospel }\end{array}$ \\
\hline $\begin{array}{l}\text { 10. Church discipline and } \\
\text { supervision }\end{array}$ & 10. External relations \\
\hline \multirow[t]{3}{*}{ 11. Alternation of the bylaws } & $\begin{array}{l}\text { 11. Church supervision and discipline } \\
\text { 11.1 Supervision } \\
\text { 11.2 Disciplinary measures } \\
\text { 11.3 Right to appeal }\end{array}$ \\
\hline & $\begin{array}{l}\text { 12. Property and other assets of the } \\
\text { church }\end{array}$ \\
\hline & 13. Alternation of the bylaws \\
\hline
\end{tabular}

property and other assets confirm this. However, the details of the two Church Orders show important differences.

Two examples serve as proof that the latest Church Order of the ACC evolved into a more ecumenical Church Order which serves the purpose of the church:

The mission statement in chapter 1 of the church order of 1999 stated that the ACKNS is a church for Afrikaans speaking Christians. This was changed to read as follows: 'As Gods children we want to create a spiritual home mainly for Afrikaans speaking people where we can serve and care for all people and in doing 
so, obey the command of Christ to make disciples of all people.' (Afrikaanse Christen Kerk van Nieu-Seeland 2010a)

The confessional foundation of the Church is then stated as follows:

The Bible as the holy and infallible Word of God is the foundation of the church. The teachings of the Church in accordance with the Word of God are expressed in the Forms of Unity as appointed by the Synod of Dordrecht in 1618-1619, namely the thirty seven articles of the Belgic Confession of Faith, the Heidelberg Catechism and the five Canons of Dordt. (Afrikaanse Christen Kerk van Nieu-Seeland 2010a)

Although the mission statement of the church seems to be exclusive by declaring that it is a church for mainly Afrikaansspeaking people, the inclusivity is defined by the word mainly. Being a church which was founded by Afrikaans-speaking immigrants for Afrikaans-speaking immigrants, it could easily have become an Afrikaans only church which would have made it totally exclusive. The fact that the Church Order states clearly that it is mainly for Afrikaans-speaking members confirms the ecumenical nature of the Church Order. It is further strengthened by the fact that the Church Order states that the Church '... can serve and care for all people and in doing so, obey the command of Christ to make disciples of all people' (Afrikaanse Christen Kerk van Nieu-Seeland 2010a). This also underlines the missionary character of the Church, which is critical for its ecumenical character. It is, however, not a church without boundaries. The reformed confessions of faith which is part of the confessional foundation of the Church define the reformed character of the Church and prepares the way for the Church's understanding of the notae ecclesiae, namely the preaching of the gospel, the understanding of the sacraments and discipline. It is also confirmed by what happens in practice in the different congregations. Although the main aim of the Church is being an Afrikaans church with a reformed character, nobody is excluded from worship, participation in church activities or even the sacraments. However, to become a member of the Church, adherence to the confessional foundation is required.

A second example of the ecumenical evolution of the Church is that of the sacraments and especially baptism. In chapter 8 , the Church Order states the following on baptism:

The symbol of water at the Holy Baptism (Math 28:18-20) is a sign of the cleansing of sin and of the new life in Christ and of the inauguration in the body of Christ. (Afrikaanse Christen Kerk van Nieu-Seeland 2010a)

Paragraph 8.2 of the same chapter reads as follows:

A minister administers baptism with water in the name of the Father and the Son and the Holy Spirit. The Church acknowledges both the covenant baptism (infant baptism) and believer's baptism (credo baptism) as substances of the sacrament. (Afrikaanse Christen Kerk van Nieu-Seeland 2010a)

How is this principle applied in the congregations? On the webpage of the congregation in Rotorua, it is explained as follows:
This means that parents have the responsibility to decide if their children will be baptised as infants or as adults when they confess their faith. Infant baptism means that babies are baptized and then escorted and taught by their parents and the church on their way to confirmation. The babies of parents who decide that their children must rather be baptised as adults with the confession of their faith, will be dedicated to the Lord. This dedication is also done by a minister. There-after parents accompany and guide their children on the road to confession of faith and baptism. (Afrikaanse Christelike Kerk Rotorua, n.d.)

This is a much more inclusive way of handling a very complicated matter and clearly shows the inclusivity of the Church. Members or groups of members do not have to baptise their children as infants, but they can guide their children on the road of faith to credo baptism. This is important because many of the Church's members come from more charismatic churches in South Africa where infant baptism is not practised. This confirms the open-endedness and the ecumenical character of the Church as stated in the Church Order. Once again, it is not without boundaries. This is confirmed by what happened at the General Assembly of the Church from 07-09 September 2012. The minister and the elders who represented the congregation of Wellington challenged the General Assembly with a declaration which stated that infant baptism was unbiblical and that they would no longer administer infant baptism in the congregation. After a long discussion, the General Assembly distanced itself from the statement by clearly reconfirming what is written in Article 8 of the Church Order. The General Assembly also told the representatives of the congregation that their decision would separate them formally from the Afrikaanse Christen Kerk van Nieu-Seeland. After the delegation from Wellington had confirmed their decision, their status in the meeting was changed from representatives to visitors. The General Assembly also decided to send the moderature to the congregation to inform them about the consequences of the decision of the Church Council (Van der Merwe 2012). This clearly underlines the fact that, although the Church is open ended and ecumenically orientated, it takes its boundaries very seriously. Adherence to the confessional foundation of the Church is important. Although both the Dutch confession of Faith and the Catechism of Heidelberg clearly states that children must be baptised, ${ }^{2}$ there is openness towards credo baptism and the dedication of children.

\section{Ministry in the Afrikaans Christian Church}

The ministry goals and the needs of the believers who founded the Church were clear from the very start. The agenda of the first working group reflects this. At the first meeting, mention was made of the structure of the Church, Sunday school, finance, a women's ministry and the organisation of weekly church services (Afrikaanse Christen Kerk van NieuSeeland 1998a). At the second meeting, Bible study groups and youth groups were added (Afrikaanse Christen Kerk van

2.Question and answer 74 of the Catechism of Heidelberg, Article 36 of the Dutch Confession of Faith (Handleiding vir die Erediens 179). 
Nieu-Seeland 1998b). The ministry goals were further defined in the proposal for the founding of the Church where it was stated that the Church would be an '... independent Afrikaans Reformed church which could accommodate the needs of Afrikaans believers and their children' (Afrikaanse Christen Kerk van Nieu-Seeland 19981). This is further confirmed by the first Church Order which clearly states that the aim of the Church is to establish a spiritual home for Afrikaans-speaking believers in New Zealand (Afrikaanse Christen Kerk van Nieu-Seeland 1999a). How these aims were realised in practice is best illustrated by studying the reports to the general meetings of the Church. For the meeting in 2007, all the congregations of the Church had to reply on six questions. The first was about church attendance and the sacraments, the second on the finances of the congregation, the third on how spiritual growth of members was facilitated, the fourth question was on service to the community and the fifth question on how the congregation experienced the blessing of the Lord. The questionnaire concluded with a question on the biggest challenge to each congregation. Hamilton reported that, out of a membership of 393 , between 150 and 200 persons attended the weekly church services. Six babies were baptised, and one was devoted. Holy Communion was celebrated on a regular basis. They also reported that members were guided in spiritual growth through sermons on Sundays and through small groups. An active men's ministry and women's ministry also contributed to spiritual growth. The congregation reached out to the community through the South-African Immigration Support Trust through which new immigrants from South Africa were physically and morally supported. The development of a viable youth ministry is mentioned as one of the biggest challenges (Afrikaanse Christen Kerk van Nieu-Seeland 2007a). North Shore reported a growth in church attendance with an almost weekly registration of new members. Spiritual growth of members was cared for in ministry groups where members were challenged to live with passion and practice their spiritual gifts. The community was served through a Bible-in-Schools project as well as through outreaches by the Promiseland Youth Ministry. The congregation further reported that they formulated a vision for the congregation, namely: 'Ons Geloofsfamilie is jubelende draers van Jesus se liefde en lig' [Our family of believers is jubilant carriers of the love and light of Jesus]. The ministry in the congregation was also described as follows in the report: Youth ministry was focused on teaching of the youth and creating a safe spiritual haven for children, teens and students. The women's ministry was called Divas and the men's ministry Macks. Pastoral care was important whilst outreach to the community as well as evangelization had a prominent standing. A small group ministry, hospitality ministry, ministry to new members, family ministry, the fete and single-parent ministry resorted under 'family of believers' (Afrikaanse Christen Kerk van Nieu-Seeland 2007c). Howick reported good attendance of church services, and the spiritual growth of members was facilitated through sermons, praise and worship and teaching. The youth ministry had a unique character through a service program which included youth from other denominations.
The community service of the congregation consisted of interdenominational Christmas services and participation in the Doulos project of the congregation (Afrikaanse Christen Kerk van Nieu-Seeland 2007b). The reports of the younger and smaller congregations like Wellington, which was only established in 2006, showed that it was not always easy to put structures in place. Nonetheless, they reported that the congregation had six small groups and an active children's ministry whilst hospitality and energy were some of the outstanding characteristics of this small congregation. The growth of the congregation is illustrated by the fact that they listed the need for a larger venue for the congregation as one of their challenges (Afrikaanse Christen Kerk van NieuSeeland 2007d).

It is clear from the above that, although relatively small in numbers, the different congregations of the ACC functioned well and covered the full complement of the ministry. From all the reports, it is evident that the focus point of all the congregations was weekly church services where praise and worship took place, teaching was done and the sacraments were celebrated. Youth ministry and small groups played a vital role whilst hospitality and reaching out to new immigrants formed a vital part of congregational life. Although the different congregations were focused on ministry to Afrikaans-speaking believers, they did not shy away from interaction with other denominations.

The ACC started off well, but will it be viable in years to come? In order to answer this question, this article will conclude with the challenges as identified by members of the Church.

\section{Challenges to the Afrikaanse Christen Kerk van Nieu-Seeland}

Being a young emigrant church in a foreign country has specific challenges. Four challenges were identified by members of the ACC.

The first major challenge is language. The mission statement of the ACC states clearly that it is a church for mainly Afrikaans-speaking people. The question that must be asked is: How will an Afrikaans church survive in an English-speaking country? The importance of this question is stressed by Thys Oosthuizen (Thys Oosthuizen, pers. comm., 30 August 2012), one of the founding members of the Church:

When people arrived in New Zealand, Afrikaans as language was important. Children who attend English schools however do not have the same affinity to the language of their parents. This means that the Afrikaans church can very easily become a one-generation church. More and more children are going to English churches where their friends are and the parents follow. The ACC is becoming a church for the elderly Afrikaners who came from South Africa.

These remarks by Oosthuizen were confirmed by the report of the congregation in Howick to the General Assembly of 
2010 when they reported as follows: 'The decline of Afrikaans as medium of instruction is becoming an increasing problem in catechesis and teaching.' This is named as the most important reason why the Rev Johan Hendricks, minister of Hamilton, confirmed that the congregation in Hamilton was planning English church services to accommodate the local community (Johan Hendricks, pers. comm., 10 September 2012). Although Afrikaans will always be important as the language of the Church, the ACC will have to make room for English as an alternative language of ministry.

A second important challenge is the ecumenical nature of the ACC. It is a Church that accommodates believers who came from different denominations in South Africa. In the case of the congregation in Hamilton, members are from as different denominations as Roman Catholic and Apostolic Faith Mission, although the majority came from the Afrikaans reformed churches. It challenges the Church to be much more open towards dogma. This is visible in the Church Order of the Church as well as in the administering of the sacraments, namely the baptism and Holy Communion. The Church allows everybody who can partake in Holy Communion in his or her church of origin to do so in the ACC.

A third challenge is socio-economic in nature. The employment of foreigners has become problematic in New Zealand. Companies are becoming more and more hesitant to employ foreigners due to political pressure (Johan Hendricks, pers. comm., 10 September 2012). The worldwide recession also means that fewer South Africans are arriving in New Zealand. This means that the traditional source of new members for the ACC has dried up. This becomes evident from the reports of the different congregations to the General Assembly in 2010. North Shore reported the recession as one of the challenges to new emigrants (Afrikaanse Christen Kerk van Nieu-Seeland 2010c:2). Auckland stated the following under challenges: 'The recession hit a significant number of our members hard. Almost $10 \%$ of our core group left the congregation for Australia or other towns in New Zealand' (Afrikaanse Christen Kerk van Nieu-Seeland 2010b:2). Christchurch reported:

Christchurch does not seem to be the best place to find work. There are not many professional jobs available. With the decrease in immigrants, our congregation stopped growing. Many members also lost their jobs due to the recession. (Afrikaanse Christen Kerk van Nieu-Seeland 2010d:2)

A fourth challenge is to stay true to the calling of the Church. According to the ministers of the ACC, one of the biggest dangers to the Church is becoming an Afrikaans cultural cluba place exclusively for Afrikaans-speaking emigrants where they could treasure and foster their culture rather than living out their calling as believers (the various personal interviews that I did refer - see reference to personal communication in text). The following quote from one of the members of the congregation in Christchurch confirms this. Zefanja Potgieter, who lived with her family in Christchurch, said: 'My Afrikaner heart became stronger and my appreciation for Afrikaans as language and my own culture was not even in South Africa as strong as it is now' (Odendaal 1999:4). The founders of the Church realised this from the outset and, for example, tried to keep their distance from the Afrikaanse Klub in Auckland. They decided not to use the infrastructure of the club to promote the Church nor did they allow the club to use the infrastructure of the Church to promote the club (Afrikaanse Christen Kerk van Nieu-Seeland 1998i:4).

\section{Conclusion}

The history of the Afrikaanse Christen Kerk van Nieu-Seeland is remarkable in many ways. Since the first congregation was founded in 1998, it grew in members, minsters and congregations from a Church with one congregation to a denomination with ten congregations. Although relatively small in numbers, the history of this emigrant Church is an example of how the devotion, vision and perseverance of a small group of Christians can overcome diversity to make a huge impact on the lives of people and the community in which they live. Important challenges lie ahead, but if the same spirit which led to the founding of the Church prevails, the ACC will not only continue to be a spiritual home to many Afrikaans-speaking Christians in New Zealand, but it will be a Church which keeps contributing to the New Zealand society.

\section{Acknowledgements Competing interests}

The author declares that he has no financial or personal relationships which may have inappropriately influenced him in writing this article.

\section{References}

Afrikaanse Christelike Kerk Rotorua, n.d., 'Doop' besigtig 13 Oktober 2012, by http://www.ackrotorua.co.nz/viewpage.php?page_id=3

Afrikaanse Christen Kerk van Nieu-Seeland, 1998a, Agenda: Werkgroep, 02 Augustus, Kerkargief.

Afrikaanse Christen Kerk van Nieu-Seeland, 1998b, Agenda: Werkgroep, 14 September 1998, Kerkargief.

Afrikaanse Christen Kerk van Nieu-Seeland, 1998c, Dokument: Kerknaam 2, Kerkargief.

Afrikaanse Christen Kerk van Nieu-Seeland, 1998d, Dokument vir Stigting van die Kerk: 1998, Kerkargief.

Afrikaanse Christen Kerk van Nieu-Seeland, 1998e, Dokument: Verkiesing van Kerkraad, Kerkargief.

Afrikaanse Christen Kerk van Nieu-Seeland, 1998f, Dokument: Verkiesing van ouderlinge, Kerkargief.

Afrikaanse Christen Kerk van Nieu-Seeland, 1998g, Geskiedenis van die Afrikaanse Christen Kerk van Nieu-Seeland, Kerkargief.

Afrikaanse Christen Kerk van Nieu-Seeland, 1998h, Notule van die Werkgroep, 02 September 1998, Kerkargief.

Afrikaanse Christen Kerk van Nieu-Seeland, 1998i, Notule van die Werkgroep, 14 September 1998, Kerkargief.

Afrikaanse Christen Kerk van Nieu-Seeland, 1998j, Notule van die Werkgroep 21 September 1998, Kerkargief.

Afrikaanse Christen Kerk van Nieu-Seeland, 1998k, Stigtingsakte, 21 September 1998, Kerkargief.

Afrikaanse Christen Kerk van Nieu-Seeland, 1998I, Stigtingsdokument: 07 Oktober 1998, Kerkargief

Afrikaanse Christen Kerk van Nieu-Seeland, 1999a, Die Kerkorde: 17 Julie 1999, Kerkargief.

Afrikaanse Christen Kerk van Nieu-Seeland, 1999b, Notule van die Kerkordewerkgroep $1 / 99$, Kerkargief.

Afrikaanse Christen Kerk van Nieu-Seeland, 1999c, Notule van die Kerkordewerkgroep 2/99, Kerkargief. 
Afrikaanse Christen Kerk van Nieu-Seeland, 1999d, Notule van die Kerkraad: 09 September 1999, Kerkargief.

Afrikaanse Christen Kerk van Nieu-Seeland, 2000, Notule van 'n Gemeentevergadering: North Shore, 27 Augustus 2000, Kerkargief.

Afrikaanse Christen Kerk van Nieu-Seeland 2001a, Notule van die Kerkraad: North Shore, 09 Augustus 2002, Kerkargief.

Afrikaanse Christen Kerk van Nieu-Seeland, 2001b, Notule van die Kerkraad: North Shore, 22 November 2001, Kerkargief.

Afrikaanse Christen Kerk van Nieu-Seeland, 2002, Notule van 'n Gemeentevergadering North Shore, 09 Junie 2002, Kerkargief.

Afrikaanse Christen Kerk van Nieu-Seeland, 2003a, Gemeenteverslag: 25 Mei 2003, Kerkargief.

Afrikaanse Christen Kerk van Nieu-Seeland, 2003b, Notule van die Kerkraad Hamilton: 28 Augustus 2003, Kerkargief.

Afrikaanse Christen Kerk van Nieu-Seeland, 2004a, Brief van Hamiltonwyk aan North Shore: 22 April 2004, Kerkargief.

Afrikaanse Christen Kerkvan Nieu-Seeland, 2004b, Notule van ' $n$ Gemeentevergadering North Shore, 16 Mei 2004, Kerkargief.

Afrikaanse Christen Kerk van Nieu-Seeland, 2005a, Notule van die Eerste Algemene Vergadering: 14 Mei 2005, Kerkargief.

Afrikaanse Christen Kerkvan Nieu-Seeland, 2005b, Notulevan 'n Gemeentevergadering: North Shore, 27 November 2005, Kerkargief.

Afrikaanse Christen Kerk van Nieu-Seeland, 2006a, Notule van die Kerkraad: North Shore, 22 November 2006, Kerkargief.

Afrikaanse Christen Kerk van Nieu-Seeland, 2006b, Notule van die Tweede Algemene Vergadering: 26 Mei 2006, Kerkargief.

Afrikaanse Christen Kerk van Nieu-Seeland, 2006c, Notule van ' $n$ Gemeentevergadering: North Shore, 26 November 2006, Kerkargief.

Afrikaanse Christen Kerk van Nieu-Seeland, 2007a, Gemeenteverslag aan die Algemene Vergadering: Hamilton 2007, Kerkargief.

Afrikaanse Christen Kerk van Nieu-Seeland, 2007b, Gemeenteverslag aan die Algemene Vergadering: Howick 2007, Kerkargief.

Afrikaanse Christen Kerk van Nieu-Seeland, 2007c, Gemeenteverslag aan die Algemene Vergadering: North Shore 2007, Kerkargief.

Afrikaanse Christen Kerk van Nieu-Seeland, 2007d, Gemeenteverslag aan die Algemene Vergadering: Wellington 2007, Kerkargief.
Afrikaanse Christen Kerk van Nieu-Seeland, 2007e, Notule van die Dagbestuur: 25 Januarie 2007, Kerkargief.

Afrikaanse Christen Kerk van Nieu-Seeland, 2007f, Verslag van die Dagbestuur aan die Algemene Vergadering: 08 September 2007, Kerkargief.

Afrikaanse Christen Kerk van Nieu-Seeland, 2010a, Die Kerkorde: Afrikaanse Christen Kerk van Nieu-Seeland, Kerkargief.

Afrikaanse Christen Kerk van Nieu-Seeland, 2010b, Gemeenteverslag aan die Algemene Vergadering: Auckland 2010, Kerkargief.

Afrikaanse Christen Kerk van Nieu-Seeland, 2010c, Gemeenteverslag aan die Algemene Vergadering: North Shore 2010, Kerkargief.

Afrikaanse Christen Kerk van Nieu-Seeland 2010d, Gemeenteverslag aan die Algemene Vergadering: Christchurch 2010, Kerkargief.

Afrikaanse Christen Kerk van Nieu-Seeland, 2012, Notule van die Negende Algemene Vergadering 2012, Kerkargief.

Afrikaanse Christen Kerk van Nieu-Seeland, 2015, Verslag van die Dagbestuur van die Algemene Vergadering: 12 April 2015, Kerkargief.

De Vries, F., 2012, Rigtingbedonnerd: Op die spoor van die Afrikaner post 1994, Tafelberg Uitgewers, Kaapstad.

Marchetti-Mercer, M.C. \& Roos, J.L., 2013, 'Afrikaanse emmigrante: Verliese en verwagtinge', LitNet Akademies 10(1).

Notule van 'n Gesamentlike Vergadering: North Shore en Howick, 28 June 1999

Notule van 'n Gesamentlike Vergadering: North Shore en Howick, 10 Julie 2000, bl. 1

Notule van 'n Gesamentlike Vergadering: North Shore en Howick, 14 Augustus 2000, bl. 1.

Notule van 'n Gesamentlike Vergadering: North Shore en Howick, 14 Augustus 2000, bl. 3.

Odendaal, N., 1999, 'Stadig skiet Afrikaners wortel in die vreemde', Rapport, 7 November, bl. 3.

Onafhanklike Gereformeerde Kerk van Howick, 1999, Brief van die Onafhanklike Gereformeerde Kerk van Howick: ACKNS, 08 Maart 1999

Presbyterian Church of Aotearoa, 1999, Letter from Kerry Enright 28 July 1999.

Rademeyer, A., 2010, 'Die stroom uit SA al dikker', Rapport, 08 November, bl. 1.

Van der Merwe, 2012, Verslag: Besoek aan Algemene Vergadering 2012.

Van der Watt, P.B., 1975, Die Ned Geref Kerk 1652-1824, NG Kerkboekhandel, Pretoria.

Van Rooyen, J., 2000, The new Great Trek: The story of South Africa's white exodus, Unisa Press, Pretoria. 